\title{
Horseradish Peroxidase Biosensor to Detect Zinc Ions in Aqueous Solutions
}

\author{
Mambo Moyo \\ Department of Chemical Technology, Midlands State University, Gweru, Zimbabwe \\ Email: moyom@msu.ac.zw
}

Received October 21, 2013; revised November 24, 2013; accepted December 5, 2013

Copyright (C) 2014 Mambo Moyo. This is an open access article distributed under the Creative Commons Attribution License, which permits unrestricted use, distribution, and reproduction in any medium, provided the original work is properly cited. In accordance of the Creative Commons Attribution License all Copyrights (C) 2014 are reserved for SCIRP and the owner of the intellectual property Mambo Moyo. All Copyright (C) 2014 are guarded by law and by SCIRP as a guardian.

\begin{abstract}
Maize tassel-multiwalled carbon nanotube (MT-MWCNT) composite has been used as a matrix for physical adsorption of horseradish peroxidase (HRP) onto the surface of a glassy carbon electrode through electrostatic interactions. The HRP/MT-MWCNT biosensor was applied for the detection of $\mathrm{Zn}^{2+}$ in aqueous solution. The biosensor designed was able to determine $\mathrm{Zn}^{2+}$ in the range of $0.35-12 \mathrm{mg} / \mathrm{L}$ with a detection limit of $7.5 \mu \mathrm{g} / \mathrm{L}$. The inhibition was found to be reversible and uncompetitive when data were modeled using the Dixon and Cornish-Bowden plots. The biosensor was found to have good repeatability, reproducibility and high selectivity. The developed biosensor can be used to detect other HRP inhibiting trace metal ions.
\end{abstract}

\section{KEYWORDS}

\section{Horseradish Peroxidase; Maize Tassel; Multiwalled Carbon Nanotubes; Metal Biosensor; $\mathbf{Z n}^{2+}$}

\section{Introduction}

Powerful analytical techniques, such as atomic absorption spectroscopy, isotope dilution inductively coupled plasma mass spectrometry, inductively coupled plasma optical emission spectrometry and voltammetric methods, are widely used and are commercially available for detecting heavy metals ions. These techniques exhibit high sensitivity, selectivity, reliability, and accuracy. On the other hand, they are very time-consuming for sample pretreatment and expensive, and they can be performed only by qualified and experienced technicians [1-3]. The heavy metals to be determined are non-degradable, cannot be detoxified biologically and can accumulate in the biosphere and transfer to the alimentary chain, thereby giving rise to potential serious health consequences for human beings, animals and plants [4]. The toxicity of heavy metal ions result mainly from their interaction with enzymes by binding to the sulfhydryl groups, leading to inhibition in metabolism and the function of numerous enzymes and hormones [5]. Of particular interest in this study is zinc metal ion. Zinc is a trace element that is essential for human health. When people absorb too little zinc they can experience a loss of appetite, decreased sense of taste and smell, slow wound healing and skin sores. Zincshortages can even cause birth defects. On the other hand, although humans can handle large concentrations of zinc, too much zinc can still cause eminent health problems, such as stomach cramps, skin irritations, vomiting, nausea and anaemia. Very high levels of zinc can damage the pancreas and disturb the protein metabolism, and cause arteriosclerosis. Zinc contagion can lead to a flulike condition known as metal fever and can be a danger to unborn and newborn children through blood or milk of their mothers when they have absorbed large concentrations of zinc. For these reasons, there is a considerable interest in the development of highly sensitive, selective, rapid and reliable analytical methods in their detection.

Enzyme based biosensors represent an alternative method to quickly detect trace metal ions through inhibition. They possess advantages such as minimum sample pretreatment, low cost and less time of analysis, and sufficient sensitivity and selectivity [6-8]. In inhibition-based enzyme biosensors, the concentration of heavy metal ions in an assayed sample is determined through either direct or indirect inhibition methods with lower detection 
limits. The detection principle of the enzyme-based biosensors is based on the target analyte selectively inhibiting the activity of the immobilized enzyme resulting in a decrease in voltammetric signal. A decrease in enzyme activity below normal values can serve as a standard measure which is an indicator of possible heavy metal poisoning.

In this study, horseradish peroxidase (HRP) was immobilized onto maize tassel-multiwalled composite (MTMWCNT) through adsorption to construct an inhibitor biosensor for the determination of $\mathrm{Zn}^{2+}$ ions in aqueous solution. The measurement was performed with $\mathrm{Zn}^{2+}$ inhibiting the catalytic activity of HRP enzyme to reduce $\mathrm{H}_{2} \mathrm{O}_{2}$. The decrease in the reduction current is expected to be proportional to the concentration of the $\mathrm{Zn}^{2+}$ ion in solution. The mode of inhibition was investigated using the Dixon and Cornish-Bowden plots.

\section{Experimental}

\subsection{Reagents and Apparatus}

All reagents were of analytical grade and were used without further purification. Horseradish peroxidase (HRP, $250 \mathrm{U} \cdot \mathrm{mg}^{-1}$ ), N,N-dimethylformamide (DMF), Nafion (5\% ethanol solution), Multi-walled carbon nanotube (MWCNT), $\mathrm{Zn}\left(\mathrm{NO}_{3}\right)_{2}$ were purchased from Sigma-Aldrich (South Africa). Hydrogen peroxide $\left(\mathrm{H}_{2} \mathrm{O}_{2}, 30 \%\right.$ w/w) was obtained from Merck (South Africa) and solutions were freshly prepared before being used. Phosphate buffer solutions with various $\mathrm{pH}$ values were prepared by mixing standard stock solutions of $0.10 \mathrm{M} \mathrm{Na}_{2} \mathrm{HPO}_{4}$ and $0.10 \mathrm{M} \mathrm{NaH}_{2} \mathrm{PO}_{4}$ and adjusting the $\mathrm{pH}$ with $0.1 \mathrm{M} \mathrm{H}_{3} \mathrm{PO}_{4}$ or $\mathrm{NaOH}$ from Merck, South Africa. All solutions were prepared using Milli-Q water (resistivity $>18 \mathrm{M} \Omega \mathrm{cm}^{-1}$ ). All electrochemical experiments were performed with a Bioanalytical Systems (USA) CV-50 W conventional three-electrode system. A three-electrode system was employed with an $\mathrm{Ag} / \mathrm{AgCl}$ as the reference electrode, a platinum wire as the counter electrode, and the modified electrodes as the working electrodes. The phosphate buffer solution was kept in thoroughly anaerobic conditions by purging it with high-purity nitrogen for at least $15 \mathrm{~min}$ before and continuously during the experiments. FT-IR spectra of the free HRP, HRP/MT-MWCNT film and MT-MWCNT film were obtained using a Nicolet 380 FT-IR spectrometer (Thermo Scientific). After enzyme immobilization, the film was scraped gently from the electrode surface. The HRP/MT-MWCNT film, free HRP and MT-MWCNT film were analyzed directly using the diamond tip in the region $400-4000 \mathrm{~cm}^{-1}$. To avoid interferences from $\mathrm{CO}_{2}$ and water, IR chamber was flushed with $\mathrm{N}_{2}$ gas and fresh background was recorded and utilized prior to recording spectra of sample. All measurements were carried out at room temperature $\left(25^{\circ} \mathrm{C} \pm\right.$ $\left.2^{\circ} \mathrm{C}\right)$

\subsection{Preparation of the Maize Tassel Powder}

The maize tassel (MT) powder was prepared using a reported procedure [9]. Briefly, maize tassel was plucked off the woody parts of the maize plant, thoroughly washed with water and air-dried at room temperature. The material was then milled and fractionated to obtain particles of diameter range of 50 - $100 \mu \mathrm{m}$ which were washed twice with $0.01 \mathrm{M}$ Hydrochloric acid $(\mathrm{HCl})$ in order to remove any impurities that might be on the powder. The acid-washed biomass was then washed twice with high purity water prior to electrode modification.

\subsection{Fabrication of HRP Biosensor}

The biosensor was prepared following the steps described in our previous work [8]. Briefly, prior to modification, the GC electrode ( $\phi=4 \mathrm{~mm}$ ) was polished to a mirror finish by use of the BASi polishing kit with 1.0, 0.3 and $0.05 \mu \mathrm{m}$ diamond slurry in sequence, rinsed thoroughly with ultra-pure water, then ultrasonically rinsed with ethanol and ultra-pure water for $10 \mathrm{~min}$ in sequence, in order to remove any adsorbed substances on the electrode surface. The cleaned GC electrode was dried in air. The composite was prepared by dispersing MT-MWCNT $(4: 1 \mathrm{w} / \mathrm{w})$ with the aid of ultrasonic agitation for $1 \mathrm{~h}$ in $10 \mathrm{~mL}$ of N,N-dimethylformamide (DMF) to give a 0.1 $\mathrm{mg} \cdot \mathrm{mL}^{-1}$ yellow-black solution. A $10 \mu \mathrm{L}$ drop of this dispersion was cast on to the surface of a GC electrode and after drying in air, $10 \mu \mathrm{L}$ horseradish peroxidase (HRP) solution (10 mg. $\mathrm{mL}^{-1}$, dissolved in $0.1 \mathrm{~mol} \cdot \mathrm{L}^{-1}$ pH 7.0 phosphate buffer solution, PBS) and $0.5 \mu \mathrm{L}$ of $0.3 \%$ Nafion to act as a binder was deposited on MT-MWCNT composite (see Figure 1).

\subsection{Inhibition Studies}

The determination on the decrease in the current obtained for the reduction of $\mathrm{H}_{2} \mathrm{O}_{2}$ by $\mathrm{HRP}$ using voltammetry was used as basis of evaluation. The process was carried out in a three step procedure. The biosensor response was first measured in 0.1 M PBS, (0.1 M KCl, pH 7.0) and $0.1 \mathrm{mM} \mathrm{H}_{2} \mathrm{O}_{2}$ to have steady-state current before inhibition $\left(\mathrm{I}_{\mathrm{i}}\right)$. The electrode was then washed with the same buffer and incubated in solution containing known concentrations of $\mathrm{Zn}^{2+}\left(0.35-6.0 \mathrm{mg} \cdot \mathrm{L}^{-1}\right)$. After incubating for $20 \mathrm{~min}$, the modified electrode response was measured and this corresponded to steady-state current after inhibition $\left(\mathrm{I}_{\mathrm{F}}\right)$. The percentage of HRP inhibition (\% $\left.\mathrm{I}_{\mathrm{HRP}}\right)$ and residual enzyme activity (\%REA $\mathrm{HRP}_{\mathrm{HR}}$ ) were calculated using Equations (1) and (2) [10]:

$$
\% \operatorname{Inhibition}(\mathrm{I} \%)=\frac{\left(\mathrm{I}_{\mathrm{i}}-\mathrm{I}_{\mathrm{F}}\right)}{\mathrm{I}_{\mathrm{i}}} \times 100
$$




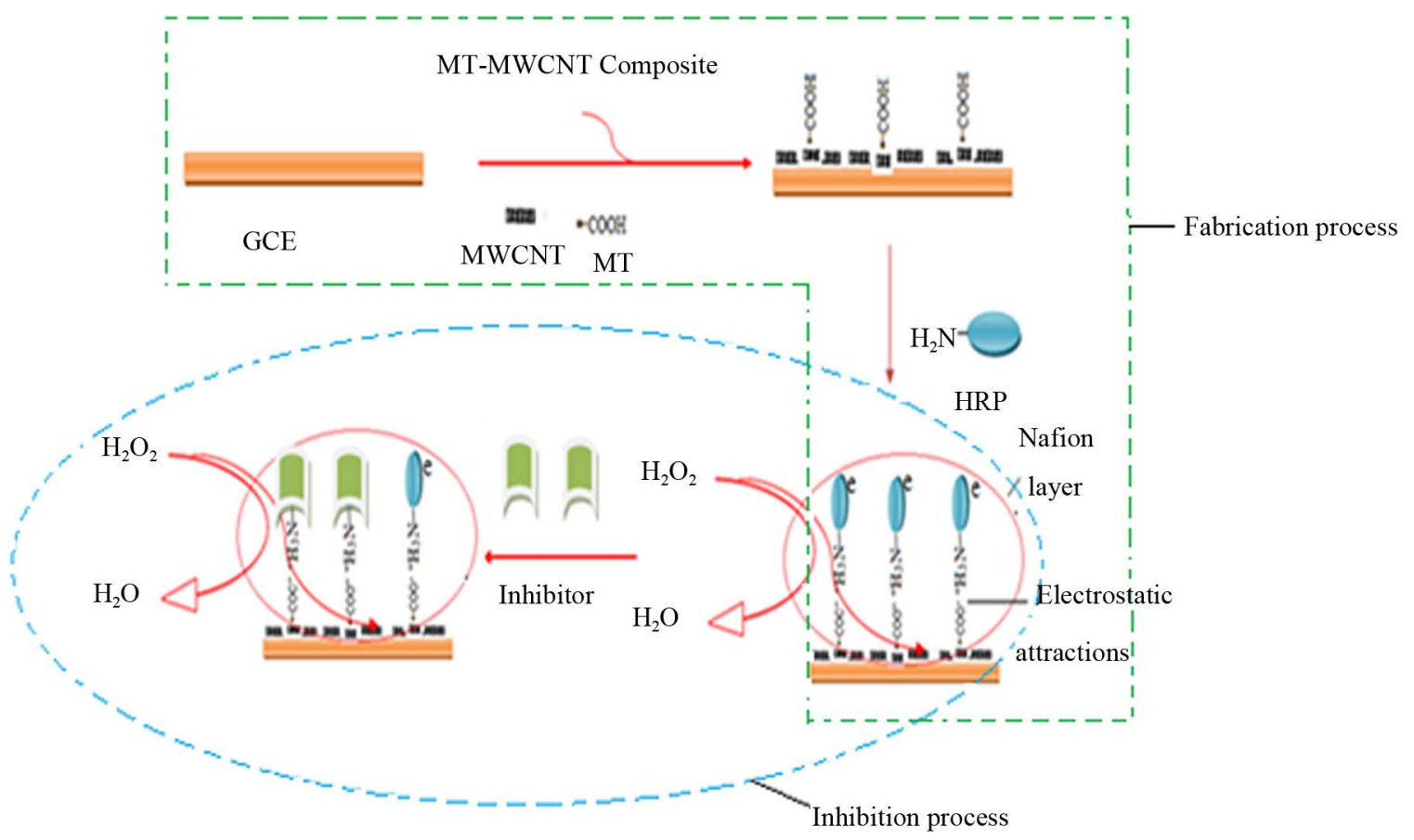

Figure 1. Schematic representation of fabrication process and inhibition process.

$\%$ Residual enzyme activity $($ REA\% $)=\frac{\left(I_{F}\right)}{I_{i}} \times 100$

\section{Results and Discussion}

\subsection{Physical Ccharacterization}

The interaction between HRP and MT-MWCNT was evaluated with the FT-IR spectra of HRP, HRP/MTMWCNT film and MT-MWCNT composite film. The shapes and positions of the amide I (1700 - $\left.1600 \mathrm{~cm}^{-1}\right)$ and amide II (1620 - $1500 \mathrm{~cm}^{-1}$ ) infrared absorbance bands of proteins provide detailed information on the secondary structure of polypeptide chain of the proteins $[11,12]$. Figure 2 (curve a) shows the FTIR spectrum of free HRP. The amide I band of HRP, which is caused by $\mathrm{C}=\mathrm{O}$ stretching vibrations of peptide linkages, appeared at $1641 \mathrm{~cm}^{-1}$. The signal at $1516 \mathrm{~cm}^{-1}$ indicates the characteristic of amide II, which may have originated from a combination of $\mathrm{N}-\mathrm{H}$ in plane bending and C-N stretching vibrations of the peptide groups. In Figure 2 (curve b) the FTIR spectrum of HRP immobilized on the surface of MT-MWCNT is shown. It can be seen in Figure 2 (curve b) that the amide I and II bands in FTIR spectrum exhibited similar shapes to that of free HRP in the FT-IR spectrum (curve a) except that the bands only shifted slightly to 1636 and $1514 \mathrm{~cm}^{-1}$, respectively. The FTIR spectrum of MT-MWCNT did not show observable peaks in the range of amides II (curve a). The FTIR results indicated that the structure of HRP remained almost unchanged in MT-MWCNT composite.

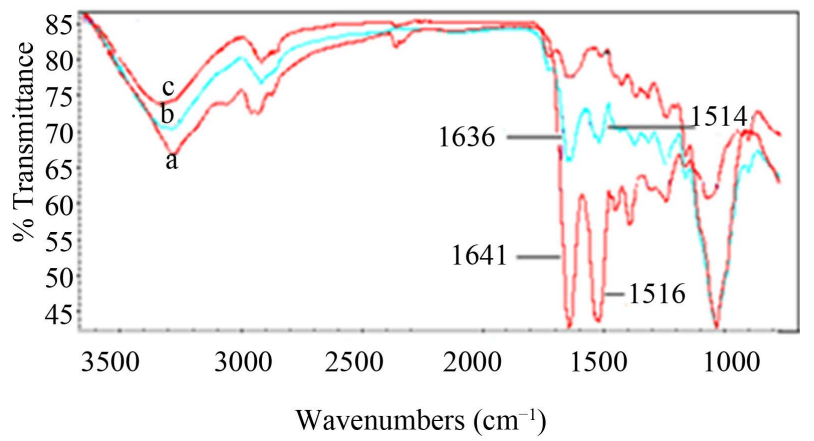

Figure 2. FT-IR spectra of the free HRP (a), HRP/MTMWCNT film (b) and MT-MWCNT film (c).

\subsection{Biosensor Characterization}

The enzymatically reduction of $\mathrm{H}_{2} \mathrm{O}_{2}$ was evaluated by using the fabricated HRP biosensor by cyclic voltammetry in $0.1 \mathrm{M}$ PBS at pH 7.0. At these experimental conditions, a cathodic peak around $-320 \mathrm{mV}$ versus $\mathrm{Ag} / \mathrm{AgCl}$ was obtained. Figure 3 shows the cyclic voltammograms of the biosensor in the absence (ab) and presence of $\mathrm{H}_{2} \mathrm{O}_{2}$ (0.01 - $0.5 \mathrm{mM}$ ) (b to f) in PBS (pH 7.0) at the scan rate of $100 \mathrm{mV} \cdot \mathrm{s}^{-1}$. An increase in cathodic peak current was observed with increase in substrate concentration.

\subsection{Inhibition Studies}

Typical percentage inhibition-concentration and percentage residual activity-concentration plots of the HRP/ MT-MWCNT biosensor under the optimized experimental conditions for $\mathrm{Zn}^{2+}$ are displayed in Figure 4. 


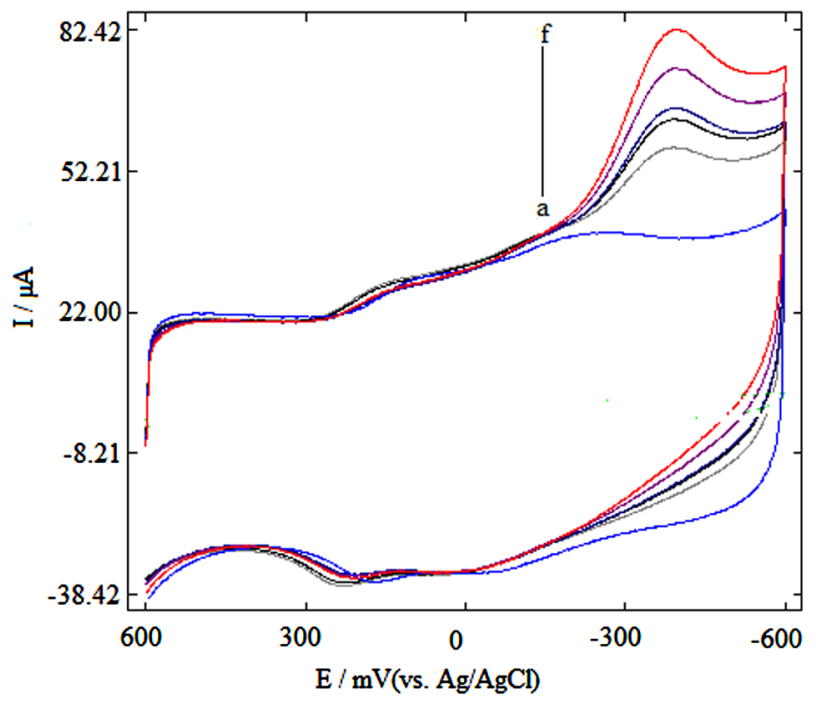

Figure 3. (A) Cyclic voltammograms of HRP biosensor in $0.1 \mathrm{M}$ PBS, pH 7.0 and 0.1 M KCl (a) without substrate, (b-f) with 0.01 - $0.5 \mathrm{mM}$ substrate.

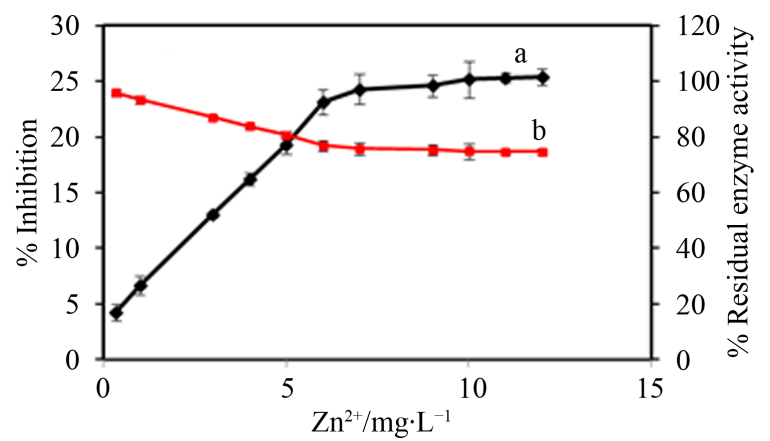

Figure 4. Dose-dependent enzyme inhibition (a) and residual enzyme activity (b) of $\mathrm{Zn}^{2+}$ towards HRP-catalyzed $\mathrm{H}_{2} \mathrm{O}_{2}$, Error bar $= \pm$ S.D. and $n=3$.

As shown in Figure 4, this type of inhibition effect exhibited dose-dependent behavior. The percentage inhibition increased with increase in concentrations of $\mathrm{Zn}^{2+}$ ions. As can be seen in Figure 4, 25.4.0\% of the activity of HRP was inhibited by $5 \mathrm{mg} \cdot \mathrm{L}^{-1}$ for $\mathrm{Zn}^{2+}$. $\mathrm{Zn}^{2+}$ had a linear range up to $12.0 \mathrm{mg} \cdot \mathrm{L}^{-1}$, and the detection limit was $7.5 \mu \mathrm{g} \cdot \mathrm{L}^{-1}$. The results obtained for this biosensor were comparable to those reported in literature. Using glucose oxidase immobilized in poly(neutral red) a linear range up to $2.5 \mathrm{mg} \cdot \mathrm{L}^{-1}$ and a detection limit of $9 \mu \mathrm{g} \cdot \mathrm{L}^{-1}$ was reported for $\mathrm{Zn}^{2+}$ [13]. In another study, $\mathrm{Zn}^{2+}$ was determined by a conductometric nitrate reductase biosensor and gave a linearity of $40 \mu \mathrm{mol} \cdot \mathrm{L}^{-1}$ and a detection limit of $0.5 \mu \mathrm{mol} \cdot \mathrm{L}^{-1}$ [14]. The residual enzyme activity decreased with increase in heavy metal ion concentration.

\subsection{Investigation on the Type of Inhibition}

The mode of enzymatic reversible inhibition is variable from one inhibitor to another, and may be competitive, non-competitive, and uncompetitive or mixed inhibition $[15,16]$. In this study, the type of inhibition shown by $\mathrm{Zn}^{2+}$ over immobilized HRP was studied using increasing concentrations of the trace metal and of the substrate, $\mathrm{H}_{2} \mathrm{O}_{2}$. Moreover, data modelling using Dixon plot (representation of the inverse of the enzyme activity vs. inhibitor concentration) and Cornish-Bowden plot (the ratio of substrate concentration and enzyme activity vs. inhibitor concentration) was utilized to verify the inhibition mode $[17,18]$. During inhibition, it should be noted that the different types of inhibition can be characterized by analyzing these two plots together. The Dixon plot by itself cannot clearly distinguish between competitive and mixed inhibition and on the other hand, the CornishBowden plot cannot always distinguish between mixed and uncompetitive inhibition. In this study, the type of inhibition shown by $\mathrm{Zn}^{2+}$ was studied using three different concentrations of $\mathrm{H}_{2} \mathrm{O}_{2}(0.05,0.2$, and $1.0 \mathrm{mM})$. Representative Dixon and Cornish-Bowden plots are shown in Figures 5A and $\mathrm{B}$ for $\mathrm{Zn}^{2+}$.

The pattern of inhibition shows that the Dixon plot lines are parallel (Figure 5A) hence the inhibition constant could not be determined. In the Cornish-Bowden plot, the lines intersect above the second quadrant above the $\mathrm{x}$-axis, giving a value of $\mathrm{K}_{\mathrm{i}}^{\prime}\left(1.2 \mathrm{mg} \cdot \mathrm{L}^{-1}\right.$ ) (see Figure $5 \mathrm{~B}$ ) and showing that the inhibition is uncompetitive. In uncompetitive inhibition, binding occurs only to ES
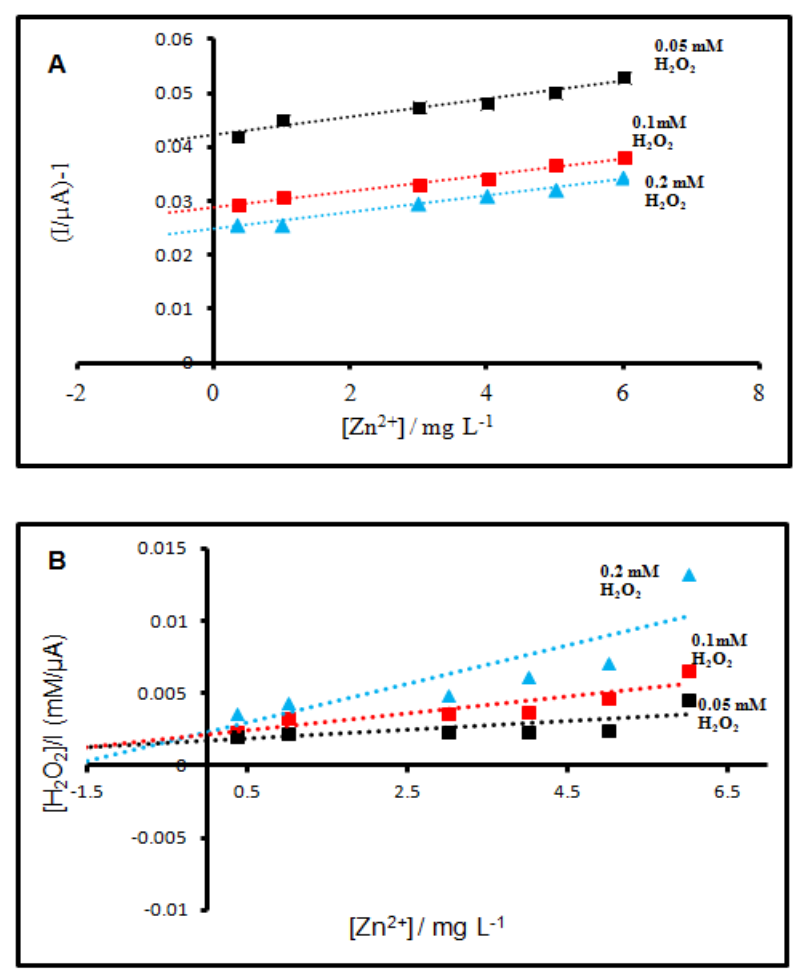

Figure 5. Dixon (A) and Cornish-Bowden (B) plots of the effect of different $\mathrm{Zn}^{2+}$ concentrations on HRP. 
complexes at locations other than the catalytic site (see Figure 6). The substrate binding modifies enzyme structure, making inhibitor-binding site available [15,16,19]. In the Figure 6, E represents the HRP enzyme; S represents $\mathrm{H}_{2} \mathrm{O}_{2}$; ES represents Compound I containing an oxylferryl centre and porphyrin cation radical; EIS represents HRP- $\mathrm{Zn}^{2+}-\mathrm{H}_{2} \mathrm{O}_{2}$ complex; I represents the $\mathrm{Zn}^{2+}$ and $\mathrm{P}$ represents $\mathrm{H}_{2} \mathrm{O}$.

\subsection{Selectivity of HRP/MT-MWCNT Biosensor}

Selectivity is an important parameter in the performance of an HRP/MT-MWCNT inhibition based biosensor. The addition of the following interferents; cations such as $\mathrm{Ca}^{2+}, \mathrm{Mg}^{2+}, \mathrm{Na}^{+}, \mathrm{K}^{+}$and anions: $\mathrm{F}^{-}, \mathrm{CN}^{-}, \mathrm{SO}_{4}^{2-}, \mathrm{CO}_{3}^{2-}$ were studied by the mixed method, using the ratio of $1: 2$ for analyte and interferents, respectively. From the results in Table 1, the cations and anions do not cause much decrease in biosensor response, except $\mathrm{CN}^{-}$anions as also reported [20].
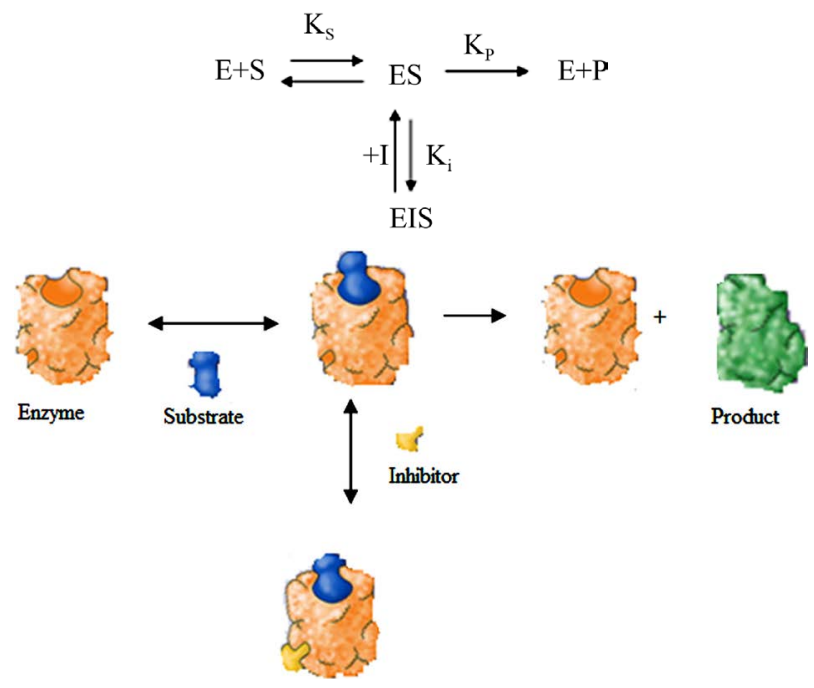

Figure 6. Mechanism for reversible, uncompetitive inhibition.

Table 1. Possible interference tested with the HRP/MTMWCNT biosensor.

\begin{tabular}{ccc}
\hline Possible interference & Ratio & \% decrease in biosensor response \\
\hline $\mathrm{Ca}^{2+}$ & $1: 2$ & $\mathrm{Zn}^{2+}$ \\
$\mathrm{Mg}^{2+}$ & $1: 2$ & 5.25 \\
$\mathrm{Na}^{+}$ & $1: 2$ & 5.56 \\
$\mathrm{~K}^{+}$ & $1: 2$ & 5.21 \\
$\mathrm{~F}^{-}$, & $1: 2$ & 3.64 \\
$\mathrm{CN}^{-}$, & $1: 2$ & 4.56 \\
$\mathrm{SO}_{4}^{2-}$, & $1: 2$ & 18.15 \\
$\mathrm{CO}_{3}^{2-}$ & $1: 2$ & 4.36 \\
\hline
\end{tabular}

\subsection{Application}

To demonstrate the feasibility of the fabricated enzyme inhibition biosensor for possible environmental applications, preliminary application of the biosensor was examined by determination of $\mathrm{Zn}^{2+}$, in tap water by standard addition method. The results are given in Table 2. The recoveries were in the range of $98.0 \%$ - $103.0 \%$, which indicated the efficacy of the biosensor for practical analysis.

The validation of the HRP/MT-MWCNT biosensor measurements against the ICP-OES technique verified the suitability of biosensor for rapid analysis of trace elements in natural water standard reference material ${ }^{\circledR}$, 1640a. The concentration of $\mathrm{Zn}^{2+}\left(3.98 \mu \mathrm{g} \cdot \mathrm{L}^{-1}\right)$ in the natural water standard reference material ${ }^{\circledR}$ from National Institute of Standard and technology (NIST) were calculated from the calibration curves. The obtained results after analysis for the trace metal presented in Table 3, corroborated well with those obtained by ICP-OES, with relative error values lower than $10 \%$.

The allowed mmaximum ccontaminant levels (MCLs) by USEPA [21] in drinking water is $1300 \mu \mathrm{g} \cdot \mathrm{L}^{-1}$ for $\mathrm{Zn}^{2+}$. The World Health Organization [22] on the other hand has given the guideline values for $\mathrm{Zn}^{2+}$, in drinking water as $2000 \mu \mathrm{g} \cdot \mathrm{L}^{-1}$. Based on this, it can be suggested that the HRP/MT-MWCNT biosensor could be used as a management tool for determining the quality of water for the presence of $\mathrm{Zn}^{2+}$ ions.

\subsection{Stability, Repeatability and Reproducibility}

The stability of the biosensor was first examined in the presence of $0.1 \mathrm{mM} \mathrm{H}_{2} \mathrm{O}_{2}$ concentration in $0.1 \mathrm{M}$ PBS (pH 7.0). For the same metal concentration, it was observed that after 10 successive series of measurements, the biosensor lost about $30 \%$ of the initial sensitivity. In studying the long-term stability, the HRP/MT-MWCNT biosensor was stored in $0.1 \mathrm{M}$ PBS at $4^{\circ} \mathrm{C}$ for 18 days and the biosensor response was tested on different days after incubation in the inhibitor. The biosensor did not

Table 2. Recovery test for $\mathbf{Z n}^{2+}$ in tap water.

\begin{tabular}{cccc}
\hline Heavy metal ion & Added $\left(\mathrm{mg} \cdot \mathrm{L}^{-1}\right)$ & Found $\left(\mathrm{mg} \cdot \mathrm{L}^{-1}\right)$ & Recovery $(\%)$ \\
\hline $\mathrm{Zn}^{2+}$ & 2.4 & 2.43 & 103.0 \\
& 2.6 & 2.58 & 98.0 \\
\hline
\end{tabular}

Table 3. Evaluation of the HRP/MT-MWCNT biosensor.

\begin{tabular}{|c|c|c|c|}
\hline \multicolumn{4}{|c|}{ Standard reference material $^{\circledR}$ 1640a-trace elements in natural water } \\
\hline Cation & HRP/MT-MWCNT biosensor & ICP-OES & $E^{a} / \%$ \\
\hline $\mathrm{Zn}^{2+}$ & $57.50 \pm 0.25$ & $55.64 \pm 0.35$ & 3.34 \\
\hline
\end{tabular}


show a bigger decrease of its initial response for $0.1 \mathrm{mM}$ $\mathrm{H}_{2} \mathrm{O}_{2}$ after incubation in standard $\mathrm{Zn}^{2+}$ ion solution for the different days studied. The repeatability of the HRP/ MT-MWCNT biosensor was investigated for fixed $\mathrm{Zn}^{2+}$ ion concentrations. Relative standard deviations (RSD) of $5.3 \%$ were obtained for $\mathrm{Zn}^{2+}$. Five modified biosensors were made independently and were investigated for the determination of the same concentrations of $\mathrm{Cu}^{2+}$. The modified biosensors showed a relative standard deviation $(R S D)$ of $\mathrm{Zn}^{2+}(4.8 \%)$.

\section{Conclusion}

The use of an HRP/MT-MWCNT biosensor for the determination of $\mathrm{Zn}^{2+}$ ions through inhibition studies has been demonstrated. It was deduced that HRP was inhibited by $\mathrm{Zn}^{2+}$ ion. The highest inhibition result obtained for the HRP/MT-MWCNT biosensor was 25.4\%. The metal ion was measured with a detection limit of 7.5 $\mu \mathrm{g} \cdot \mathrm{L}^{-1}$. By modelling the data and using the CornishBowden together with Dixon plots, the inhibition was determined to be reversible and uncompetitive. The proposed biosensor does not require any complicated immobilization procedure for the construction and has been shown to detect low concentration in samples.

\section{Acknowledgements}

The author would like to acknowledge Midlands State University.

\section{REFERENCES}

[1] R. B. Thompson, B. P. Maliwal, V. L. Feliccia, C. A. Fierke and K. McCall, "Determination of Picomolar Concentrations of Metal Ions Using Fluorescence Anisotropy: Biosensing with a "Reagentless" Enzyme Transducer,” Analytical Chemistry, Vol. 70, No. 22, 1998, pp. 4717-4723. http://dx.doi.org/10.1021/ac980864r

[2] I. Bontidean, C. Berggren, G. Johansson, et al., "Detection of Heavy Metal Ions at Femtomolar Levels Using Protein-Based Biosensors,” Analytical Chemistry, Vol. 70, No. 19, 1998, pp. 4162-4169. http://dx.doi.org/10.1021/ac9803636

[3] S. Han, M. Zhu, Z. Yuan and X. Li, "A Methylene Blue-Mediated Enzyme Electrode for the Determination of Trace Mercury(II), Mercury(I), Methylmercury, and Mercuryglutathione Complex,” Biosensors and Bioelectronics, Vol. 16, No. 1-2, 2001, pp. 9-16. http://dx.doi.org/10.1016/S0956-5663(00)00114-7

[4] M. R. Guascito, C. Malitesta, E. Mazzotta and A. Turco, Inhibitive Determination of Metal Ions by an Amperometric Glucose Oxidase Biosensor: Study of the Effect of Hydrogen Peroxide Decomposition," Sensors and Actuators B: Chemical, Vol. 131, No. 2, 2008, pp. 394-402. http://dx.doi.org/10.1016/j.snb.2007.11.049

[5] E. Ghica, R. C. Carvalho, A. Amine and C. M. A. Brett,
“Glucose Oxidase Enzyme Inhibition Sensors for Heavy Metals at Carbon Film Electrodes Modified with Cobalt or Copper Hexacyanoferrate," Sensors and Actuators B: Chemical, Vol. 178, 2013, pp. 270-278.

http://dx.doi.org/10.1016/j.snb.2012.12.113

[6] S. Rodriguez-Mozaz, M. J. L. De Alda and D. Barcelo, "Biosensors as Useful Tools for Environmental Analysis and Monitoring," Analytical and Bioanalytical Chemistry, Vol. 386, No. 4, 2006, pp. 1025-1041. http://dx.doi.org/10.1007/s00216-006-0574-3

[7] Z. S. Yang, W. L. Wu, X. Chen and Y. C. Liu, “An Amperometric Horseradish Peroxidase Inhibition Biosensor for the Determination of Phenylhydrazine," Analytical Science, Vol. 24, No. 7, 2008, pp. 895-899. http://dx.doi.org/10.2116/analsci.24.895

[8] M. Moyo, J. O. Okonkwo and N. M. Agyei, “A Novel Hydrogen Peroxide Biosensor Based on Adsorption of Horseradish Peroxidase onto a Nanobiomaterial Composite Modified Glassy Carbon Electrode,” Electroanalysis, Vol. 25, No. 8, 2013, pp. 1946-1954.

http://dx.doi.org/10.1002/elan.201300165

[9] M. Moyo, L. Chikazaza, B. C. Nyamunda and U. Guyo, "Adsorption Batch Studies on the Removal of $\mathrm{Pb}(\mathrm{II})$ Using Maize Tassel Based Activated Carbon,” Journal of Chemistry, Vol. 2013, Article ID: 508934, 8 p.

[10] P. Raghu, T. M. Reddy, B. E. K. Swamy, B. N. Chandrashekar, K. Reddaiah and M. Sreedhar, "Development of AChE Biosensor for the Determination of Methyl Parathion and Monocrotophos in Water and Fruit Juices: A Cyclic Voltammetric Study,” Journal of Electroanalytical Chemistry, Vol. 665, 2012, pp. 76-82. http://dx.doi.org/10.1016/j.jelechem.2011.11.020

[11] Z. Li and N. Hu, "Direct Electrochemistry of Heme Proteins in Their Layer-By-Layer Films with Clay Nanoparticles,” Journal of Electroanalytical Chemistry, Vol. 558, 2003, pp. 155-165.

http://dx.doi.org/10.1016/S0022-0728(03)00390-5

[12] Y. Liu, H. Liu and N. Hu, "Core-Shell Nanocluster Films of Hemoglobin and Clay Nanoparticle: Direct Electrochemistry and Electrocatalysis,” Biophyscal Chemistry, Vol. 117, No. 1, 2005, pp. 27-37

[13] M. E. Ghica and C. M. A. Brett, "Glucose Oxidase Inhibition in Poly (Neutral red) Mediated Enzyme Biosensors for Heavy Metal Determination,” Microchimica Acta, Vol. 163, No. 3-4, 2008, pp. 185-193.

http://dx.doi.org/10.1007/s00604-008-0018-1

[14] X. Wang, S. Xia, J. Zhao, H. Zhao and J. N. Renault, "Inhibitive Determination of Heavy Metal Ions by Conductometric Nitrate Reductase Biosensor,” Chem. Res. Chinese Universities, 2009, Vol. 25, pp. 443-445

[15] F. Arduini, A. Amine, D. Moscone and G. Palleschi, "Reversible Enzyme Inhibition-Based Biosensors: Applications and Analytical Improvement through Diagnostic Inhibition,” Analytical. Letters, Vol. 42, No. 9, 2009, pp. 1258-1293. http://dx.doi.org/10.1080/00032710902901913

[16] G. L. Turdean, "Design and Development of Biosensors for the Detection of Heavy Metal Toxicity," International Journal of Electrochemistry, Vol. 2011, 2011, pp. 1-15. 
http://dx.doi.org/10.4061/2011/343125

[17] A. Cornish-Bowden, "A Simple Graphical Method for Determining the Inhibition Constants of Mixed, Uncompetitive and Non-Competitive Inhibitors,” Biochemical Journal, Vol. 137, 1974, pp. 143-144.

[18] M. Dixon, "The Determination of Enzyme Inhibitor Constants,” Biochemistry Journal. Vol. 55, No. 1, 1953, pp. 170-171.

[19] A. Amine, H. Mohamed, I. Bourais and G. Palleschi, "Enzyme Inhibition-Based Biosensors for Food Safety and Environmental Monitoring," Biosensors and Bioelectronics, Vol. 21, No. 8, 2006, pp. 1405-1423. http://dx.doi.org/10.1016/j.bios.2005.07.012
[20] Y. Yang, M. Yang, H. Wang, J. Jiang, G. Shen and R. Yu, "An Amperometric Horseradish Peroxidase Inhibition Biosensor Based on a Cysteamine Self-Assembled Monolayer for the Determination of Sulphides.” Sensors and Actuators B: Chemical, Vol. 102, No. 1, 2004, pp. 162168. http://dx.doi.org/10.1016/j.snb.2004.04.016

[21] USEPA, "USEPA Maximum Contaminant Level Goals and National Primary Drinking Water Regulations for Lead and Copper,” Final Rule, Federal Register, Vol. 56, No. 110, 1991, pp. 26460-26469.

[22] World Health Organization (WHO), “Guidelines for Drinking Water Quality,” 3rd Edition, 2004, WHO, Geneva. 